\title{
Molecular Methods for the Analysis of Gut Microbiota
}

\author{
Pawel Namsolleck ${ }^{1}$, Ralph Thiel ${ }^{1}$, Paul Lawson ${ }^{2}$, Kim Holmstrøm $^{3}$, Mirjana Rajilic ${ }^{4}$, \\ Elaine E. Vaughan ${ }^{4}$, Lionel Rigottier-Gois ${ }^{5}$, Matthew D. Collins ${ }^{2}$, Willem M. de Vos $^{4}$ and \\ Michael Blaut ${ }^{1}$
}

From the ${ }^{1}$ German Institute of Human Nutrition Potsdam-Rehbruecke, Nuthetal, Germany, ${ }^{2}$ School of Food Biosciences, University of Reading, UK, ${ }^{3}$ Department of Molecular Characterization, Bioneer A/S, Hørsholm, Denmark, ${ }^{4}$ Laboratory of Microbiology, Wageningen University, The Netherlands and ${ }^{5}$ Institut National de la Recherche Agronomique, Jouy en Josas, France

Correspondence to: Michael Blaut, German Institute of Human Nutrition Potsdam-Rehbruecke, Arthur-Scheunert-Allee 114-116, 14458 Nuthetal, Germany. E-mail: blaut@mail.dife.de

\begin{abstract}
Microbial Ecology in Health and Disease 2004; 16: 71-85
This review focuses on methodological approaches used to study the composition of human faecal microbiota. Gene sequencing is the most accurate tool for revealing the phylogenetic relationships between bacteria. The main application of fluorescence in situ hybridization (FISH) in both microscopy and flow cytometry is to enumerate faecal bacteria. While flow cytometry is a very fast method, FISH microscopy still has a considerably lower detection limit. Key words: DGGE, TGGE, dot blot, FISH, flow cytometry, gut ecology, in situ gene expression, micro-array, sequencing.
\end{abstract}

\section{INTRODUCTION}

The microbial community resident in the human intestinal tract has a considerable effect on health and well-being and has been implicated in both beneficial and adverse health effects. Diet is a major factor that affects the composition and the activity of the gut microorganisms. In order to influence the gut microbiota in a targeted way it is paramount to better characterize this microbial community. In the last decades, culture-independent methods based on 16S rRNA gene analysis have been applied to various microbial habitats. Easy-to-use methods are urgently required so as to be able to study the influence of diet on gut microbiota composition in large numbers of subjects. As the conventional methods for analysing the intestinal microbiota are time-consuming and tedious, high-throughput methods for the automated detection of fluorescently labelled cells based on microscopic image analysis, flow cytometry and DNA arrays are being developed.

\section{PHYLOGENETIC MARKERS}

In the 1970s, Carl Woese and co-workers $(1,2)$ identified $16 \mathrm{~S}$ rRNA as an extremely useful phylogenetic marker, which has found a wide range of applications in microbial taxonomy and microbial ecology. Ribosomal RNA is the preferred molecule for bacterial identification and systematics. The information content of a marker molecule is defined as the log (base 2) of the number of possible character states ( 4 for nucleotides, 20 for amino acids) times the length of the sequence. Table I shows the information content of several marker molecules. The number of variable, and therefore informative, residues is the most important parameter for the applicability of the marker. The most widely used marker, the 16S rRNA, contains 974 variable residues for the domain Bacteria. The 23S rRNA contains more than twice as much information as the $16 \mathrm{~S}$ rRNA and can be used as an additional marker for bacterial phylogeny.

It should be noted, however, that the discriminative power of the 16S rRNA has its limitations $(3,4)$. It has been demonstrated that the use of protein-coding gene sequences may be more effective for bacterial identification (5). Owing to the low evolutionary rate of the $16 \mathrm{~S}$ rRNA genes, some ecologically distinct bacterial taxa cannot be distinguished. The 16S rRNA marker molecule is very useful for distinguishing moderately divergent populations. However, very closely related populations can be better distinguished by other means.

One of the phylogenetically interesting protein-coding genes is $\operatorname{gyr} B$ (encoding the subunit B of the bacterial DNA gyrase). The rate of horizontal gene transfer of this gene is low and it evolves at a higher rate than the rRNA gene (6). Phylogenetic trees based on the $16 \mathrm{~S}$ rRNA sequences diverge less than gyrB-based trees. Other phylogenetic markers of interest are the $16 \mathrm{~S}-23 \mathrm{~S}$ intergenic spacer region $(7,8)$, the $\inf B$ gene (encoding the translation 
Table I

Information content of phylogenetic marker molecules for the domain Bacteria (4, modified)

\begin{tabular}{|c|c|c|c|c|c|c|c|c|}
\hline & \multicolumn{8}{|l|}{ Molecule } \\
\hline & \multicolumn{2}{|l|}{ 16S rRNA } & \multicolumn{2}{|l|}{ 23S rRNA } & \multicolumn{2}{|l|}{$\mathrm{EF}-\mathrm{Tu}$} & \multicolumn{2}{|l|}{$\begin{array}{l}\text { ATPase } \\
\beta \text {-subunit }\end{array}$} \\
\hline Size $(E$. coli $)$ & $1542 n$ & & $2904 n$ & & 394 aa & & 460 aa & \\
\hline Information (bits)* & 3084 & & 5808 & & 1706 & & 1992 & \\
\hline Conservation $^{\dagger}$ & Cons. & Var. & Cons. & Var. & Cons. & Var. & Cons. & Var. \\
\hline & 568 & 974 & 934 & 1970 & 83 & 311 & 111 & 359 \\
\hline Information (bits) & 1948 & & 3940 & & 1347 & & 1555 & \\
\hline
\end{tabular}

$\mathrm{n}$, nucleotides; aa, amino acids.

*Logarithm (base 2) of the number of possible character states ( $4 \mathrm{n} ; 20$ aa) times the number of (E. coli) positions.

${ }^{\dagger}$ Number of conserved (Cons.) and variable (Var.) positions.

${ }^{*}$ Logarithm (base 2) of the number of possible character states (4 n; 20 aa) times the number of variable positions.

initiation factor 2) (9), the ATPase $\beta$-subunit (10) and the elongation factor $\mathrm{Tu}$ (11). Table II shows examples of sequence databases of various phylogenetic markers.

In the future, classification of bacteria will be based on combinations of two or more unlinked phylogenetic markers. This could improve our understanding of the diversity and complexity of bacterial ecosystems.

\section{PHYLOGENETIC DIVERSITY OF THE HUMAN GUT MICROBIOTA}

The gastrointestinal tract (GIT) of humans is colonized by an extremely complex and diverse assemblage of microorganisms. Estimations indicate that it harbours approximately $10^{14}$ bacterial cells, which is approximately 10 times more than all tissue cells of the human body taken together. The GIT is inhabited by several hundred prokaryotic species, the majority of which are strict anaerobes belonging to the bacterial domain.

The taxonomic diversity of intestinal bacteria has been the subject of intense investigations over the last decades. In the 1970s and the 1980s, analysis of the microbial community in the human gut was largely dependent on the use of powerful enrichment procedures and the ability to grow strict anaerobes. The isolates were identified and characterized by various phenotypic methods. In a pioneering study, Moore and Holdeman (12) analysed the faecal flora of 20

\section{Table II}

\begin{tabular}{lll}
\multicolumn{3}{l}{ Sequence databases } \\
\hline Phylogenet on different
\end{tabular}

male Japanese-Hawaiians. The total number of different bacterial species was estimated to exceed 400 or 500 , although the actual number of identified species was only 113. Subsequent studies confirmed the great diversity of intestinal bacteria. The genera Bacteroides, Bifidobacterium, Clostridium, Eubacterium, Fusobacterium, Lactobacillus, Peptostreptococcus, Ruminococcus and Streptococcus were the first dominant taxa identified.

\section{S rRNA GENE SEQUENCING AND PHYLOGENETIC ANALYSIS}

During the last decade, it has become clear that the taxonomic and phylogenetic diversity of the human gut microbiota has been grossly underestimated. This was caused by our inability to: a) reliably identify bacteria and recognize new species diversity and $b$ ) isolate and cultivate organisms by conventional microbiological methods.

The 16S rRNA gene has revolutionized the way taxonomists classify and identify bacteria. Through this approach, evolutionary relationships between organisms can be determined objectively by comparison of their rRNA gene sequences. Differences in compared sequences can be used to measure evolutionary distances, and phylogenetic relationships can be presented in the form of phylogenetic trees. Because 16S rRNA molecules contain regions with different degrees of variability (varying from conserved to highly variable regions) it is possible to distinguish organisms at different phylogenetic levels (from species to domain). Furthermore, many tens of thousands of bacterial $16 \mathrm{~S}$ rRNA gene sequences are now available, including virtually all validly described species, which enables newly determined sequences to be compared to existing sequences and/ or organisms. In collaboration with various laboratories, 16S rRNA gene sequencing has been used as a tool to search for new human intestinal bacteria. By sequencing short amplified rDNA fragments (approximately 500 bases proximal to the $5^{\prime}$ end of rRNA, which include diagnostic variable regions $\mathrm{V} 1, \mathrm{~V} 2$ and $\mathrm{V} 3$ ) this approach was used to 
perform rapid phylogenetic identification on several hundred strictly anaerobic cultures. Although the great majority of isolates ( $>90 \%$ ) were readily assigned to established species, a large number of organisms possessed sequences which did not correspond to sequences available in any of the public sequence databases. These organisms have subsequently been subjected to detailed phylogenetic analysis based on full 16S rRNA gene sequences, and shown to correspond to hitherto unknown genera and/or species. Although detailed phenotypic characterization studies are ongoing on many of the unknown isolates, a plethora of new human intestinal species have now been formally described (Table III) and several others are pending.

Although the 16S rRNA gene sequencing of traditionally isolated and cultivated bacteria is adding to our knowledge of the diversity of the GIT microflora, many organisms cannot be cultivated and are therefore not yet included in conventional microbiological analysis. In recent years, polymerase chain reaction (PCR)-rDNA cloning and sequencing strategies have been used increasingly to directly access the phylogenetic diversity of bacteria within complex communities. By using universal primers, rRNA genes from potentially all bacteria in a sample can be amplified together, without cultivation and purification of organisms. Amplified rDNA products can then be cloned to obtain individual genes, which can be sequenced and subjected to phylogenetic analysis. Using this approach bacterial phylotypes can be readily identified by phylogenetic analysis of their sequences. Even if a sequence is novel, its position on the phylogenetic tree can be determined. This sequencing strategy was used to more comprehensively explore the phylogenetic diversity of faeces and colonic tissues. From earlier reports (13-15) and ongoing studies in our laboratories, it is now apparent that the great majority of bacterial species identified from the GIT using this culture-independent approach represent novel, previously undescribed

\section{Table III}

Recently described new bacterial taxa from the human gut andlor faeces

\begin{tabular}{lll}
\hline Genus & Species & Reference \\
\hline Anaerostipes & A. caccae & $(70)$ \\
Anaerotruncus & A. colihominis & $(71)$ \\
Anaerofustis & A. stercorihominis' & Finegold et al., \\
stercorihominis' & & unpublished \\
Alistipes & A. finegoldii & $(72)$ \\
& A. putridinis & $(72)$ \\
Bryantella & B. formatexigens & $(73)$ \\
Cetobacterium & C. somerae & $(74)$ \\
Clostridium & C. bolteae & $(75)$ \\
& C. hathewayi & $(76)$ \\
Dorea & D. longicatena & $(77)$ \\
Ruminococcus & R. luti & $(78)$ \\
'Subdoligranulum' & 'S. variabile' & Holmstrøm et al., \\
& & unpublished \\
\hline
\end{tabular}

species. Furthermore, it is now evident that the most prevalent sequence types fall into three main phylogenetic groupings referred to as the Bacteroides group, Clostridium coccoides group and Clostridium leptum group (Figs. 1-3). Although our studies are still ongoing, they have already provided a wealth of information on species diversity, including the recognition of many new rDNA phylotypes and sequences, and the phylogenetic distribution of the predominant gut bacteria.

\section{FLUORESCENCE IN SITU HYBRIDIZATION}

The principle of fluorescence in situ hybridization (FISH) is the detection of a target DNA or RNA site by a fluorescently labelled probe molecule. Based on the knowledge of the 16S rRNA sequence information it is possible to design a probe that specifically targets a given organism. Since each bacterial cell contains $10^{3}-10^{5}$ ribosomes, the rRNA probes find a sufficiently high number of targets to result in the illumination of the target cell.

FISH is a powerful method for the enumeration of bacteria in complex habitats such as the human gut. Most notably, it does not require cultivation of the target organisms. In previous years the number of probes available for the detection of intestinal bacteria has increased steadily. The developed probes target the bacteria at several levels of phylogenetic hierarchy. Table IV lists the most widely used probes for the characterization of the human gut microbiota. The list consists primarily of probes that target dominant phylogenetic groups.

Although FISH has been used widely in bacterial ecology, the method has to be adapted to the habitat under investigation and the type of samples analysed. The protocol of FISH has been optimized for the analysis of human faecal samples.

A fresh faecal sample has to be thoroughly homogenized by rough shaking and the use of glass beads. This is a very important step, because only a small amount of the sample is analysed, therefore, it must be representative of the whole sample. Subsequently, large particles are removed by a brief centrifugation at low centrifugal force $(\leq 300 \mathrm{~g})$. Aliquots of the supernatant are subsequently fixed with paraformaldehyde and in parallel with ethanol (16). These treatments permeabilize the majority of cells. However, a number of primarily Gram-positive cells are not sufficiently permeabilized by this treatment and are therefore additionally treated with lysozyme or a lipase, which may help to render the cell envelope of the bacteria more permeable (17).

Although FISH samples for microscopy are usually prepared on glass slides, it is not necessary to use a transparent medium. Since the excitation light comes through the objective from above the sample, any surface can be used. Pernthaler et al. use filter membranes to concentrate the cells from a marine habitat by filtration. In 


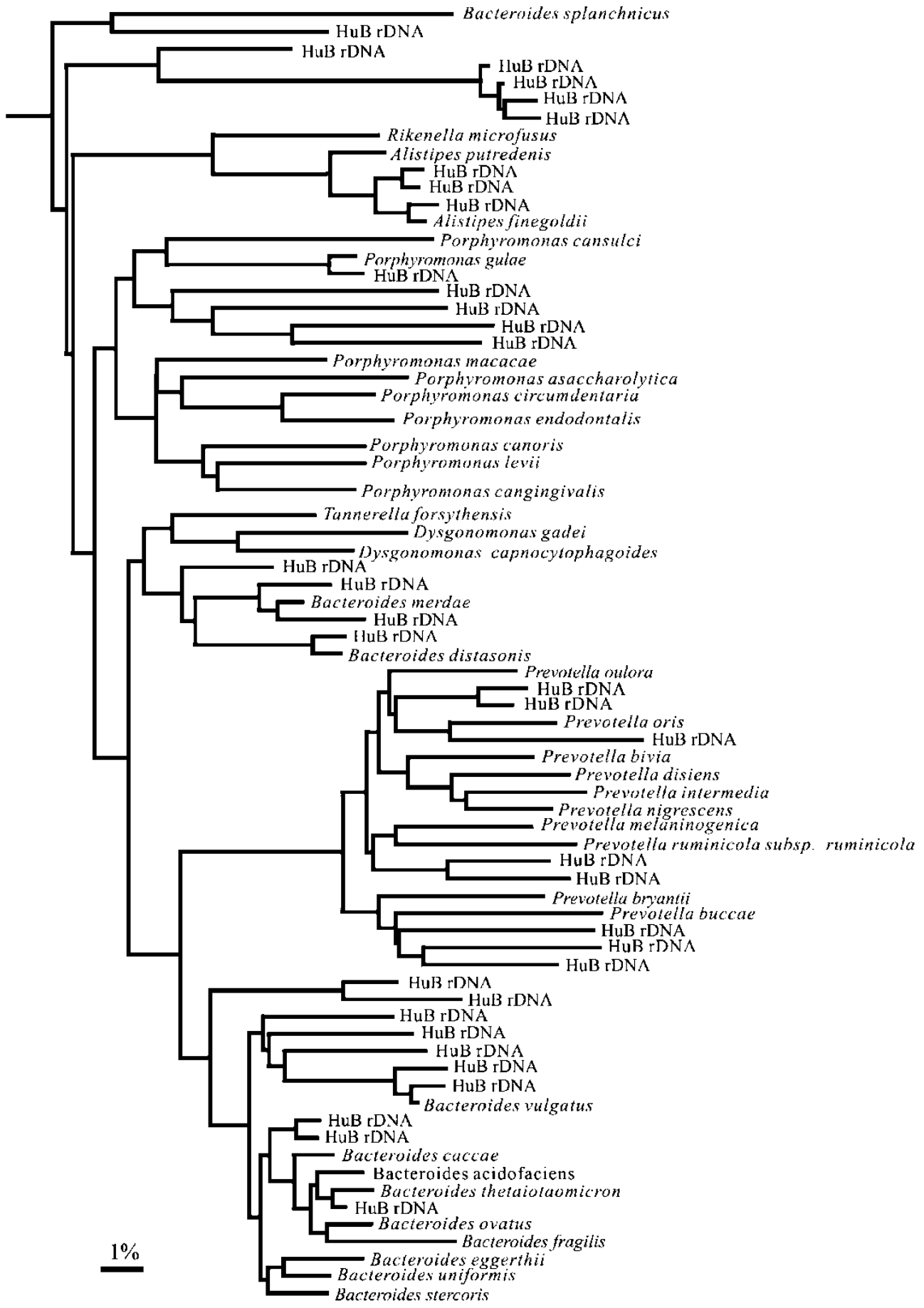

Fig. 1. The distribution of representative rDNA lines within the Bacteroides phylogenetic group derived from human colonic bacteria, which do not correspond to taxonomically defined species. HuB rDNA, clone derived from human GIT flora.

this case, the bacterial cells are visualized on the membrane (18).

\section{Probes}

Most probes targeting the bacterial 16S rRNA have a length of 15-23 nucleotides. To make them detectable the probes are labelled with fluorochromes at their $5^{\prime}$-end. The choice of the fluorochrome depends on the available light source of the microscope and the corresponding filter sets. The small bandwidth of the excitation wavelength principally allows the use of several probes, each labelled with a different fluorochrome, within the same sample. The use of several probes enables the simultaneous detection of several target organisms in a microbial ecosystem. 


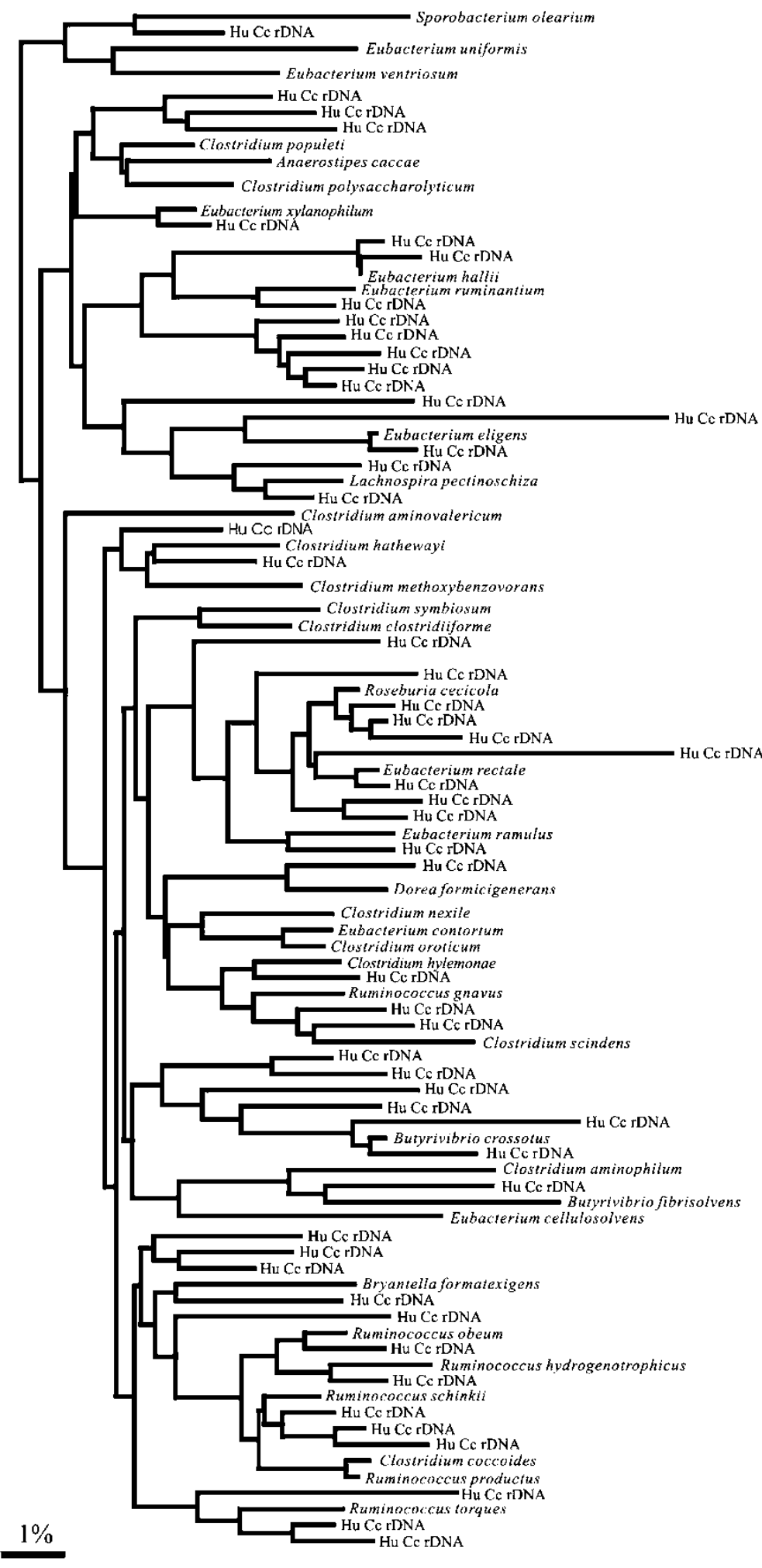

Fig. 2. The distribution of representative rDNA lines within the Clostridium coccoides phylogenetic group derived from human colonic bacteria, which do not correspond to taxonomically defined species. $\mathrm{HuCc}$ rDNA, clone derived from human GIT flora.
Prior to probe design and validation it is recommended to check whether a probe for the target group has already been described. To facilitate the search, an online database is available, which allows a search to be carried out for target organisms or probe names (probeBase; http://www.microbial-ecology.de/probebase) (19). This database also gives 


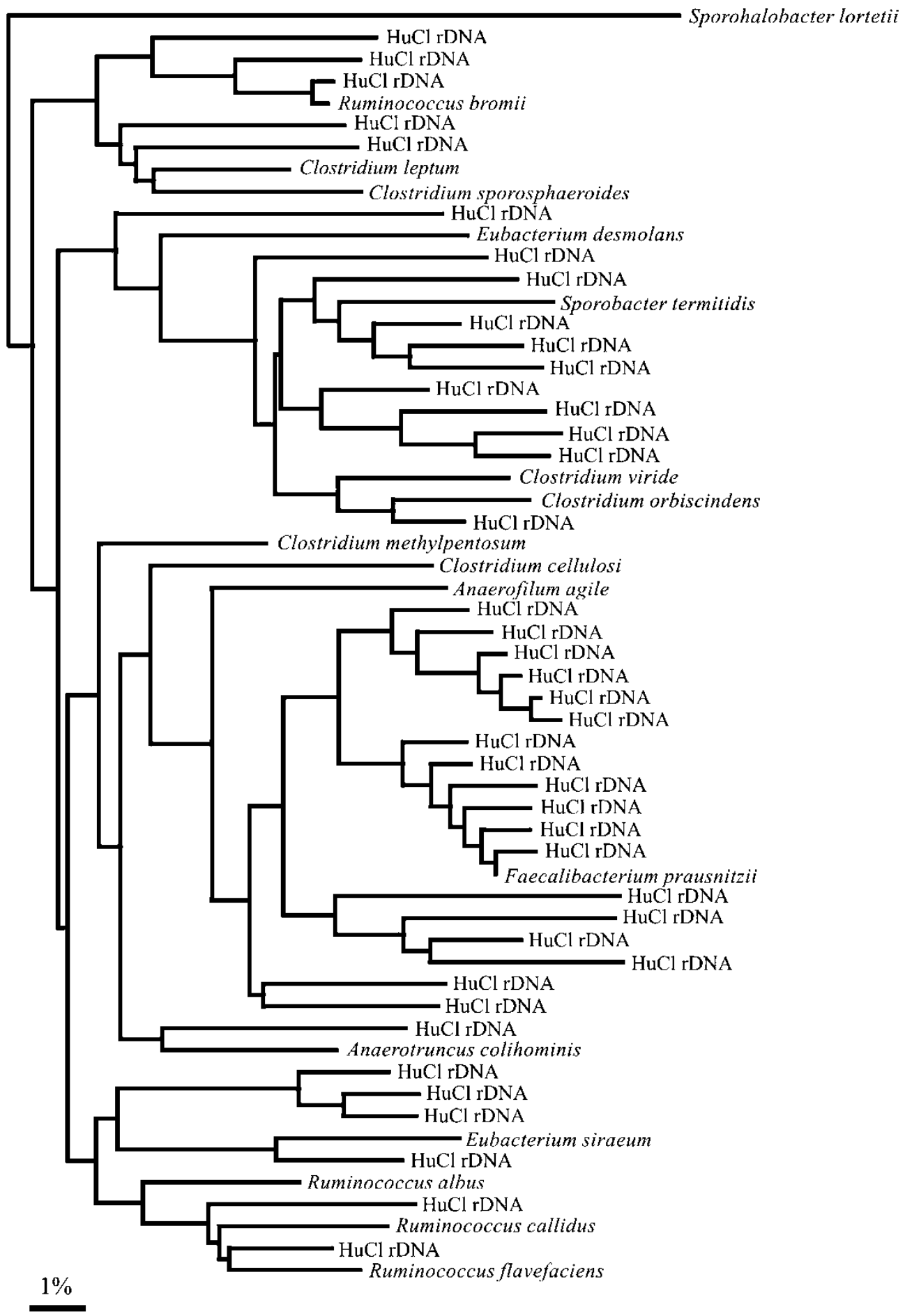

Fig. 3. The distribution of representative rDNA lines within the Clostridium leptum phylogenetic group derived from human colonic bacteria, which do not correspond to taxonomically defined species. $\mathrm{HuCl} \mathrm{rDNA}$, clone derived from human GIT flora.

more detailed information about the probes, including the optimal hybridization conditions and the specificity. Probes can be designed to detect microorganisms at different phylogenetic levels (from species to domain) using rRNA regions that differ in their extent of conservation. To design a probe that hybridizes only with the target organism(s), it is recommended that only complete $16 \mathrm{~S}$ rRNA sequences are used (20). The most commonly used sequence databases are 
Table IV

Exemplary list of FISH probes with sequences, names and references

\begin{tabular}{lllll}
\hline Probe & Sequence from 5' to 3' end & OPD $^{1}$ code & Reference & Notes $^{2}$ \\
\hline EUB 338 & GCTGCCTCCCGTAGGAGT & S-D-Bact-0338-a-A-18 & $(30)$ & Domain-specific \\
Acac194 & CTATACTGCCAGGGCTTT & S-S-Acac-0194-a-A-18 & $(79)$ & Butyrate producer \\
Ato 291 & GGTCGGTCTCTCAACCC & S-*-Ato-0291-a-A-17 & $(80)$ & $0.2-7 \%(81)$ \\
Bac 303 & CCAATGTGGGGGACCTT & S-*-Bacto-0303-a-A-17 & $(83)$ & $2-5.5 \%(82)$ \\
Bif 164 & CATCCGGCATTACCACCC & S-G-Bif-0164-a-A-18 & $(26)$ & $0.2-1.5 \%(26) 2.3-4.4 \%(82)$ \\
E.bif462 & CCCTTACTACTCACTCAC & S-S-Ebif-0462-a-A-18 & $(84)$ & $0.1-3.3 \%(84)$ \\
Ecyl 387 & CGCGGCATTGCTCGTTCA & S-*-Ecyl-0387-a-A-18 & $(81)$ & $0.1-7 \%(81)$ \\
Enter 1432 & CTTTTGCAACCCACT & S-*-Ent-1432-a-A-15 & $(39)$ & Potentially pathogens \\
Erec 482 & GCTTCTTAGTCARGTACCG & S-*-Erec-0482-a-A-19 & $(24)$ & $23-35 \%(24) 9-27 \%(82)$ \\
Fprau 645 & CCTCTGCACTACTCAAGAAAAAC & S-*-Fprau-0645-a-A-23 & $(37)$ & $10-17 \%(37)$ \\
Lab 158 & GGTATTAGCAYCTGTTTCCA & S-G-Lab-0158-a-A-20 & $(17)$ & Used as probiotics \\
Rbro 730 & TAAAGCCCAGYAGGCCGC & S-*-Rbro-0730-a-A-18 & $(81)$ & Together \\
Rfla 729 & AAAGCCCAGTAAGCCGCC & S-*-Rfla-0729-a-A-18 & & \\
Rint1102 & GCTTACCCGCTGGCTACT & S-S-Rint-1102-a-A-18 & $(79)$ & Butyrate producer \\
Strc 493 & GTTAGCCGTCCCTTTCTGG & S-*-Strc-0493-a-A-19 & $(24)$ & Potentially pathogens \\
Veil 223 & AGACGCAATCCCCTCCTT & S-*-Veil-0223-a-A-18 & $(81)$ & $0-4.5 \%(81)$ \\
NON 338 & ACATCCTACGGGAGGC & Not applicable & $(85)$ & Negative control \\
\hline
\end{tabular}

${ }^{1}$ Standardized nomenclature of oligonucleotide probes (86).

${ }^{2}$ Percentages are relative to the total cell count that was also detected by FISH.

the Ribosomal Database Project II (RDP-II, http:// rdp.cme.msu.edu/html) and GenBank (http://www.ncbi. nlm.nih.gov /Genbank).

Probe design is a process that includes several steps: identification of short regions in a sequence alignment existing only in the target group, generation of several oligonucleotide probes targeting organisms of interest, modification of the probe sequence to optimize the hybridization conditions (such as melting temperature), in silico validation of the newly designed probes (21). There are a few parameters characterizing a 'good' oligonucleotide probe: a minimum of one mismatch to the same region in all non-target sequences, central position of the mismatch in the non-target sequences (it decreases the stability of probe-non-target rRNA hybrids), $\mathrm{G}+\mathrm{C}$ content in the range of $50-60 \%$ (it influences the hybrid stability), high accessibility to the target region leading to a high relative fluorescence intensity (see below), no self-complementarity - which can hinder the formation of probe-target hybrids (although an influence of hairpins or dimer formation on the success of FISH analysis is not observed) $(20,21)$.

Two computer programs for probe design are available: PRIMROSE (http://www.cf.ac.uk/biosi/research/biosoft) and the 'Probe Design Tool' of the ARB software package (available at http://arb-home.de/). A special feature of ARB is the alignment of new sequences, which can be integrated in the existing 16S rRNA database of the program. However, only the PRIMROSE software allows the generation of oligonucleotides with degenerate positions (22). These probes are important when phylogenetically diverse groups of organisms are to be targeted.

When a new probe is designed and optimized, the in silico validation can be performed by the 'Probe Match' analysis function of RDP-II or the 'Basic Local Alignment Search Tool' (BLAST, http://www.ncbi.nlm.nih.gov/blast). The ideal probe targets all organisms of interest and shows no non-specific binding. However, especially for probes that target phylogenetically diverse groups, this is a difficult task.

Since the rRNA structure of the target organisms cannot be predicted in detail, a systematic experimental specificity testing of every probe using pure cultures is required. Fuchs and co-workers systematically tested the accessibility of different target sites of the rRNA of Escherichia coli. They developed a set of 171 probes that hybridized to $E$. coli cells and the binding of the probes was subsequently measured by flow cytometry. The intensity of the resulting fluorescence was taken as a direct measure for the accessibility of the rRNA molecule. Bright probe signals - which mean a good accessibility - were reported, as well as totally blocked sites (23). Although these data were obtained for E. coli only, it is very likely that differences in the accessibility of potential target sites exist in other species, as well. Therefore, new probes developed by rRNA sequence alignments have to be tested for their in situ accessibility prior to use. The ideal target region is highly specific and accessible for a given probe.

The aim of a specificity test is to find hybridization and washing conditions that lead to a specific recognition of the target organisms, while at the same time, non-target organisms must not be detected. Two problems may occur. On the one hand, the target region has to be accessible for the probe molecules. The addition of osmotically active compounds, such as dextran sulfate, to the hybridization buffer may increase the hybridization rate of the molecules (24). Another possibility to increase the access of the probe molecule to its target is the addition of helper oligonucleo- 
tides to the hybridization mixture. These unlabelled molecules are directed against flanking regions of the target. By binding to a nearby region of the target site, they can help to dissociate RNA secondary structures or RNA-protein binding and thus allow a better access of the labelled probe to its target. On the other hand, false-positive binding to non-target regions has to be avoided. In this case, the stringency of the hybridization has to be increased by the addition of formamide to the hybridization buffer or by increasing the hybridization temperature. Unlabelled competitor probes can be used specifically for species that are known to give a false-positive signal. The sequence of the competitor probe has a higher specificity to the rRNA of the false positive organisms than the labelled probe and therefore occupies the target site without giving a fluorescence signal.

To find optimal hybridization conditions that afford high specificity and signal intensity often means to find a compromise between these two effects. It should be realized that in most cases only close relatives are included in specificity testing. Therefore it cannot be excluded that a given probe sequence finds a target region that was not predicted by the previous database analyses.

\section{FISH microscopy}

In fluorescence microscopy, the detection limit of labelled cells is mainly determined by the magnification of the microscope, the dilution by the fixation and the number of microscopic fields analysed. Usually this limit lies at approximately $10^{6}$ cells per gram of sample (25).

Manual microscopic enumeration is a very tedious and time-consuming task. For studies involving the analysis of large numbers of samples and probes, the use of an automated enumeration method is highly recommended. Several systems suitable for the fully automatic detection and enumeration of FISH signals have been described. In all cases, a computer-controlled microscope is used to change the position of every microscopic field, wells and slides. A cooled, charge-coupled device (CCD) camera captures images of the microscopic fields that are sent to the analysis software for signal detection and counting. The most important advantage of an automated enumeration system is the speed of analysis, but additionally the resulting systematic error no longer varies from person to person (26). In 1999, Jansen and co-workers developed an automated system for the detection and enumeration of faecal bacteria (27). They were able to analyse 1200 images within $20 \mathrm{~h}$. At 25 images per sample, this corresponded to 48 samples. Other automated systems have been described for marine (18) and oral microbiota $(28,29)$.

An important task for the automated system is focusing. Jansen et al. used a stack of images, which were taken at a distance of $1 \mu \mathrm{m}$ in z-axis (on top of each other at the same microscopic field), to calculate the focus position (27).
Pernthaler et al. used a software autofocusing routine, which was performed in fluorescence mode at each position before the image was captured. When this focusing routine failed three times in a row, a bright-field autofocus was performed. As the samples were applied to membrane filters, the focusing routine was now able to use the high contrast of the pores of the membrane filters to restore the focus, and subsequently continue in fluorescence mode (18).

When the captured image is stored in the computer system, the analysis software has to perform a series of operations to correctly detect and count bacterial signals. Initially, a threshold-based routine classifies every pixel of the image into signal or background, resulting in a binary image, containing only black pixels as a background and white pixels as potential signals. Positive signals from the faecal bacteria form areas of white pixels with roughly the same shape and size as the bacteria. With the naked eye, fluorescent signals of bacterial cells can be distinguished easily from artefacts such as autofluorescing plant cells and mineral particles or clumps of fluorescent dyes by virtue of their shape and fluorescence intensity. For the computer software, specific parameters have to be defined that are able to separate signals from artefacts. The most important parameter is the size of a fluorescing object. If the targeted cells are cocci with a projected size of $1 \mu^{2}$, for example, objects exceeding this size can be rejected. Moreover, it has to be defined which range of signal intensity an object may have relative to the background. Finally, these signals have to be counted and calculated back into cell numbers by multiplying them by the preparative dilution factors and the microscopic magnification factor.

Enumeration of fluorescently labelled bacterial cells by flow cytometry

Flow cytometry (FCM) is a commonly used method in medical diagnostics and immunology and the enumeration of blood and other cells is a predominant application. This high-throughput method has also been used in environmental microbiology. In 1990, Amann et al. (30) presented a combination of FISH with FCM for the analysis of defined mixtures of bacteria for the first time. Since then, FCM has been applied to the analysis of various microbial ecosystems $(31-33)$

In FCM, cells (Fig. 4) are passed through a capillary, where they are detected in a focused light beam. Using a differential pressure system, it is possible to produce a laminar flow effect which causes the sample fluid to flow in a central core and prevents mixing with the sheath fluid. Several detection methods are applied to bacterial cells: forward (FSC), 90 light scatter (SSC) and fluorescence emission (FL) at different wavelengths. The FCS detection indicates the cell size, while SSC gives a measure of the granularity. Plots of FSC versus FL or of SSC versus FL 


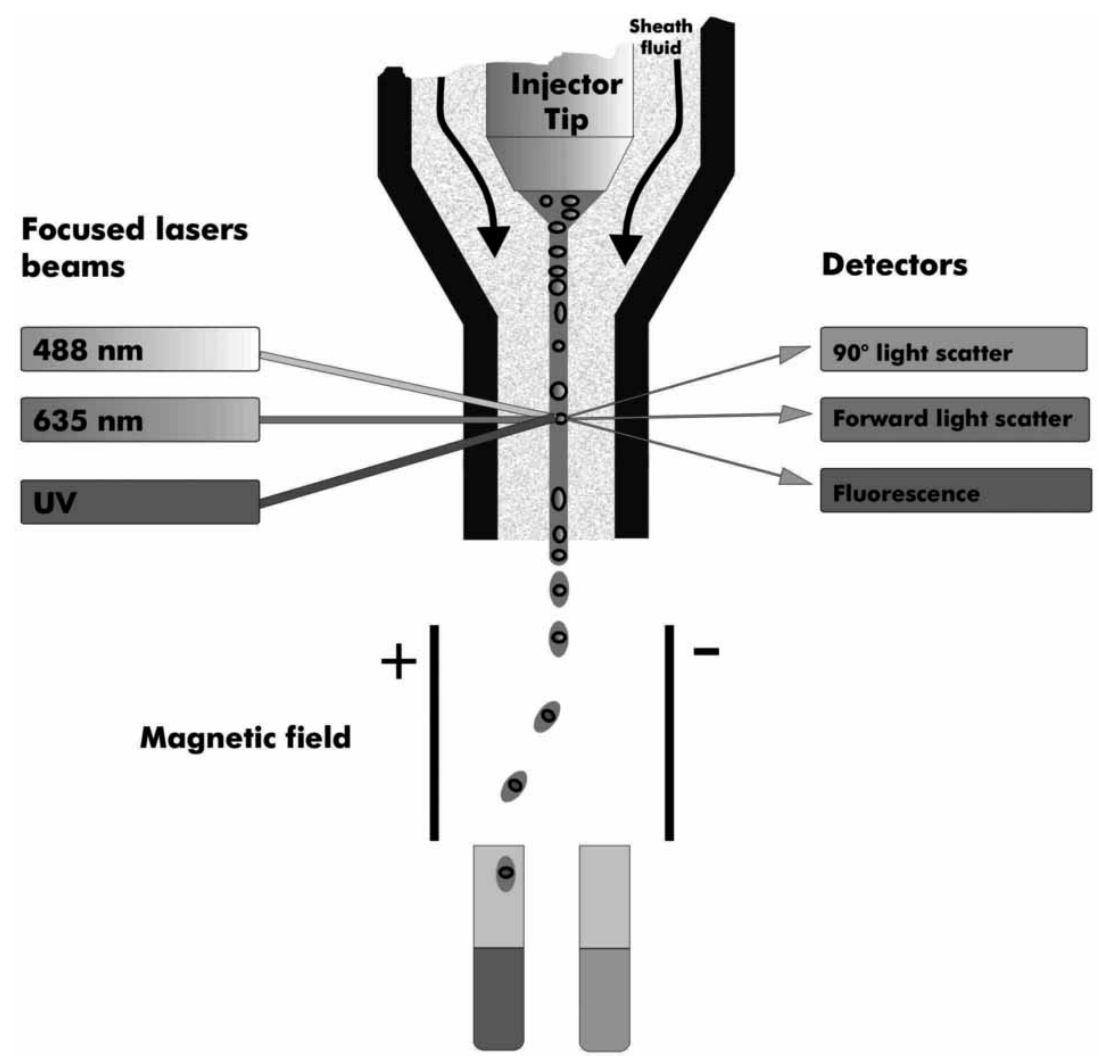

Fig. 4. Schematic drawing of a flow cell and principle of cell detection. Using a differential pressure system, cells flow 'focused' in a central core. Laser illuminated cells are detected in a small optical window by different detectors. Signals obtained from each object are electronically analysed and can be used for operating the cell sorter. facilitate the distinction of different microbial populations in a given sample.

In principle, the same probes used for the microscopic detection of fluorescent cells can also be used for detection by FCM. In addition to the specific probe for the detection of the target organisms, the probe Eub338 is used to detect all bacteria and Non338 (Table IV) is used to detect unspecific background binding $(31,34)$. All preparation steps including permeabilization, hybridization and washing can be performed on standard 96-well plates. An autosampler also decreases the time necessary for sample analysis. The detection limit of the flow cytometric approach $\left(2 \times 10^{8}\right.$ cells per gram of faeces $)$ is somewhat higher than that of the microscopy-based approach $\left(10^{6}\right.$ per gram of faeces).

In order to compare the two methods, Zoetendal and coworkers enumerated Ruminococcus obeum-like bacteria using FISH-FCM and FISH microscopy (32). Faecal samples obtained from three individuals were analysed over a period of 4 weeks using the probes Urobe63 (targeting uncultured $R$. obeum-like bacteria) and Erec 482 (targeting the Clostridium coccoides-Eubacterium rectale group). The numbers obtained with the two methods were similar (on average $2.5 \%$ for $R$. obeum-like bacteria and $16 \%$ for the $C$. coccoides- $E$. rectale group).
FISH-FCM is a powerful tool for fast, high-throughput enumeration of faecal bacteria. It has already been applied to large studies such as 'Microbe diagnostics' and 'Crownalife' (QLK1-2000-00108 and QLK1-2000-00067), in which over 400 samples are being analysed with approximately 20 oligonucleotide probes. FCM also allows cell sorting and thereby the enrichment of a defined bacterial population by up to 280 -fold which can be used for subsequent investigations $(35,36)$.

\section{QUANTITATIVE DOT BLOT}

Quantitative dot blot hybridization was originally introduced for investigating bacterial diversity (16). This method requires the isolation of rRNA from environmental samples. The rRNA is immobilized on a nylon membrane and hybridized with ${ }^{32} \mathrm{P}$ or fluorescently labelled probes. The signal intensity of each spot can be quantified. Dot blot hybridization has been widely used to determine the specificity of new oligonucleotide probes and the optimal hybridization conditions including hybridization temperature and formamide concentration $(24,37,38)$. This method has also been used for a comparison of bacterial groups in caecal and faecal samples $(39,40)$. Using rRNA dot blot hybridization and FISH combined with FCM, RigottierGois and co-workers (34) analysed the composition of 
faecal samples from 23 individuals. There were no statistically significant differences between the results obtained with the two methods for the groups of C. coccoides (mean $22 \%)$, F. prausnitzii (11.3\%), Bifidobacterium spp. (3.9\%) and enterobacteria $(2.8 \%)$. However, differences between both methods for members of the Bacteroides $(41.7 \%$ dot blot, 9.1\% FCM) and Atopobium (0.3\% dot blot, 2.8\% FCM) groups were observed. These differences can be explained by the principal differences between the two methods - the rRNA dot blot hybridization reflects the status of metabolic activity $(41,42)$, while the FISH method enumerates the target cells.

\section{MICRO-ARRAYS}

Micro-array technology allows the parallel analysis of RNA and DNA of thousands of genes, or of the same gene from thousands of organisms, in a single experiment. In microbiology, micro-arrays were initially used for exploring transcriptional profiles and genome differences for a variety of microorganisms (43). Several recent publications described micro-array systems for analysing the diversity of bacterial communities based on the $16 \mathrm{~S}$ rRNA gene or other functional genes (44-46).

Figure 5 shows the principle of the micro-array technique. Total DNA or RNA is isolated from an environmental sample and fragmented. The fragments are subsequently amplified by PCR and simultaneously labelled by the use of labelled nucleotides (in the following referred to as DNA arrays) or the fragments are directly labelled chemically (in the following referred to as RNA arrays) and hybridized to oligonucleotide probes immobilized on a glass or a membrane surface. After a washing step, a probe-target duplex can be visualized using a fluorescence scanner.

The stringency of the hybridization is the key for the analysis. The detection of a single species in the presence of a mostly unknown genetic background is difficult, because a single mismatch may already lead to incorrect results (47). However, it is difficult to find a set of conditions suitable for all probes (48). Therefore, thermal dissociation analysis of all hybrids performed on a single micro-array can help to better distinguish between matched and mismatched probe-target duplexes (48). Melting $\left(T_{\mathrm{d}}-\right.$ dissociation temperature) profiles are collected by simultaneously increasing the array temperature and measuring the fluorescence intensity of each spot. Since the effect of position and type of a mismatch on $T_{\mathrm{d}}$ of hybrids is non-linear, standard statistical methods are not suitable for data set analysis (49).

The common strategy, where DNA is amplified and labelled during PCR (DNA array), is a simple highly sensitive method. The usefulness of DNA micro-arrays in microbial ecology has been demonstrated for sulfate-reducing bacteria (50), cyanobacteria (51) and faecal bacteria (52). However, amplification steps often introduce biases that lead to false results $(13,48)$. Therefore, another strategy employs labelled rRNA, which is hybridized to immobilized DNA capture probes (RNA arrays) (53). Since the detection of RNA arrays is less sensitive, it is only possible to detect species present in relatively high numbers. Therefore, an approach was presented by Small et al. (47), who improved the specificity of the hybridization and the detection limit by using a chaperone-detector probe strategy. The principle of this approach is the application of a labelled detector probe that binds to a target near the capture region. It stabilizes the target RNA-capture hybrid and thus leads to higher signal intensity and specificity. The detection limit reported for this strategy was $0.5 \mu \mathrm{g}$ of total RNA, representing approximately $7.5 \times 10^{6}$ cells, a value that is similar to that reported for DNA micro-arrays (47).

\section{DGGE/TGGE}

In 1993, Muyzer et al. (54) introduced denaturing gradient gel electrophoresis (DGGE) for the analysis of the diversity

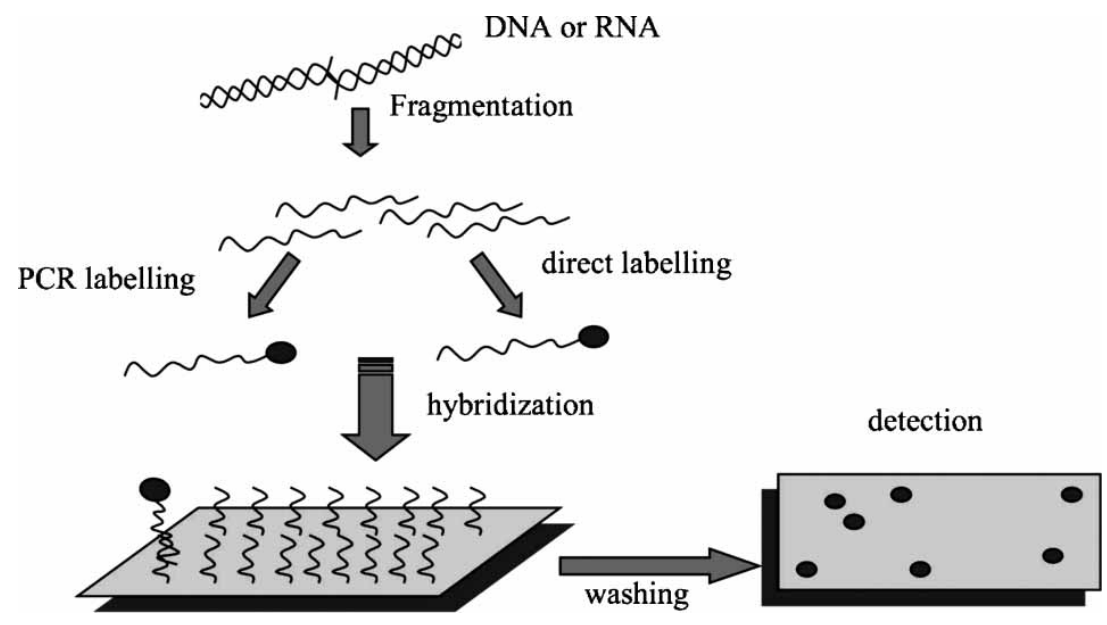

Fig. 5. Principle of the micro-array technique. DNA probe molecules (capture DNA) are immobilized on a matrix, such as glass, silicon or nylon membranes. The target molecules bind to the capture DNA and non-specifically bound molecules are washed off the surface. The remaining hybridized molecules can be detected by fluorescence imaging. 
of complex microbial ecosystems. In this method (Fig. 6), PCR-amplified fragments of $16 \mathrm{~S}$ rDNA are separated in polyacrylamide gels, containing a gradient of denaturing agents (urea or formamide). Heteroduplexes of different amplicons (with different $\mathrm{G} / \mathrm{C}$ content) are dissociating at different positions in the denaturing gradient, resulting in a hold of migration. The result is a pattern of bands, which is characteristic of the bacterial community present in the sample. In principle, each band represents one species. In a similar method - temperature gradient gel electrophoresis (TGGE), DNA fragments are separated in a temperature gradient instead of a denaturing gradient. Using universal 16S rDNA primers, the estimated detection limit is approximately $1 \%$ of the total bacterial content $(54,55)$. Fine analysis of bacterial diversity using T/DGGE is possible, but some modifications are required. Using group-specific primers, it is possible to analyse bacterial communities at a higher resolution and a lower limit of detection. In some cases, the blotting of DNA fragments separated by $\mathrm{T} /$ DGGE on a nylon membrane and hybridization using specific probes can be helpful. For correct identification of bacteria presented on T/DGGE gels, sequencing of the bands is required.

T/DGGE methods are mostly used for the investigation of the dynamics of bacterial compositions in various ecosystems (13, 56). Zoetendal and colleagues analysed faecal samples obtained from 16 healthy individuals by TGGE (55). Two of the individuals were investigated over a period of 6 months. They demonstrated that the TGGE band pattern is specific for each individual. However, some

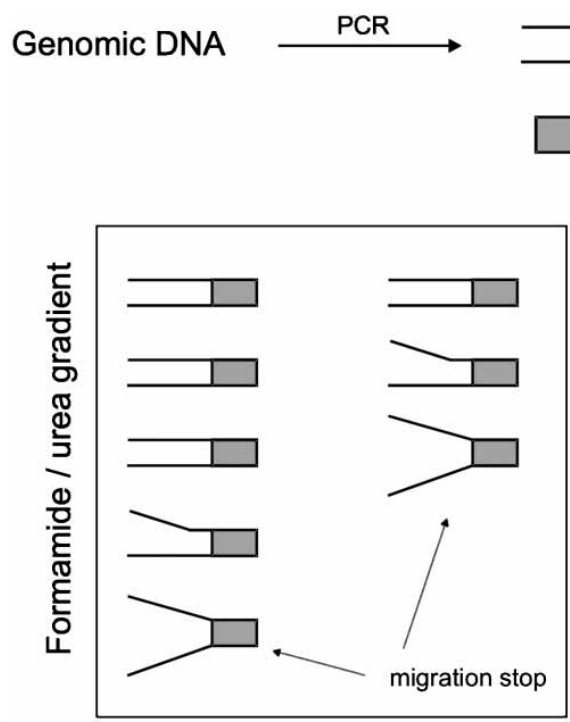

Fig. 6. Principle of the T/DGGE technique. Fragments of $16 \mathrm{~S}$ rRNA genes (usually $300-500 \mathrm{bp}$ ) are amplified. One of the primers used in the PCR reaction has a GC-clamp (GC-rich 5 end), which prevents complete denaturation of the heteroduplexes separated in a gradient gel. Different amplicons migrate to different positions (so-called melting domains), where the denaturing conditions are specific for the nucleotide sequence. of the bands were present in all faecal samples. Patterns of the bands analysed in individuals over a period of 6 months were highly constant.

In the 'Microbe Diagnostics' project, DGGE was used for assessing the intestinal microbiota profiles of ulcerative colitis (UC) patients. Faecal samples from 33 volunteers in an active state of disease were analysed by DGGE. The profiles show that the total bacterial community is complex and differences between the patients can be observed (Fig. 7). These observations of high individual variability are similar to previous observations resulting from the analyses of faecal bacterial communities from healthy volunteers. Although each UC patient has a unique microbiota composition, there were also some common bands in a number of DGGE profiles. Preliminary sequencing results (data not shown) indicate that diseased subjects investigated in two study centres in Europe (Barcelona, Spain and Cork, Ireland) share some bacteria that have not yet been detected in faeces from healthy subjects.

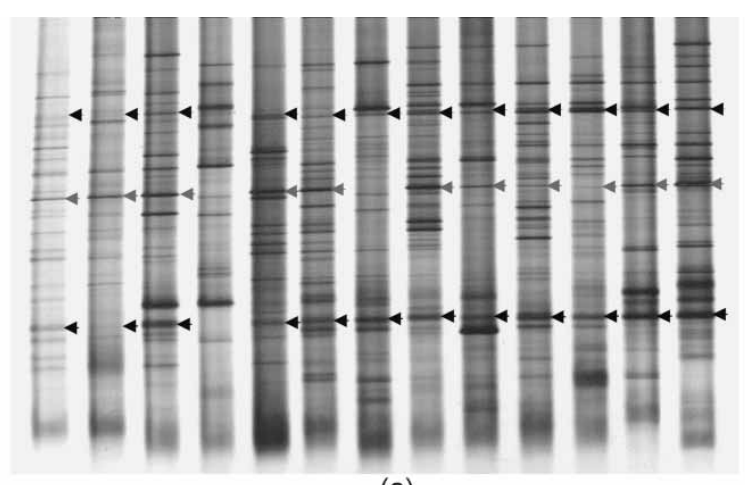

(a)

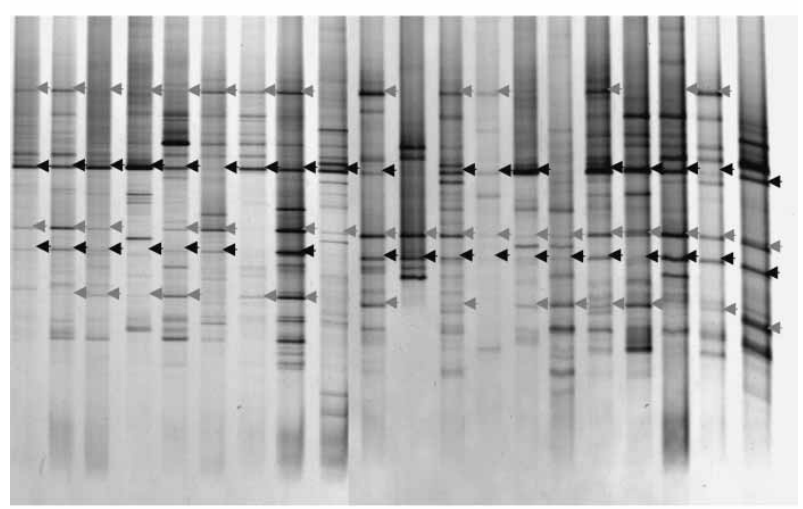

(b)

Fig. 7. Total bacterial DGGE profiles from $33 \mathrm{UC}$ patients (33 faecal samples used in this study were collected as part of the PROGID project - QLK1-2000-108). The subjects who donated faecal samples had active ulcerative colitis and they originated from two geographic locations: (a) Cork, Ireland (13 samples) and (b) Barcelona, Spain (20 samples). DNA isolation, PCR and DGGE analysis of the $\mathrm{V} 6-\mathrm{V} 8$ region of the $16 \mathrm{~S}$ rDNA were performed as described previously $(55,69)$. 


\section{IN SITU MONITORING OF GENE EXPRESSION}

There is an urgent need not only to be able to identify the individual bacterial constituents of the human intestinal microbiota, but also to assess the metabolic activity of the bacteria in the gut. One approach to meet this goal is directed at monitoring gene expression at the cellular level. The degree of expression of an enzyme is usually correlated with its activity. This leads to the assumption that the level of mRNA is a measure for the activity of the corresponding gene.

The number of mRNA molecules in an individual cell usually is not high enough to allow their direct detection by in situ hybridization analogously to the well-established FISH technique (57). In order to circumvent this problem a number of studies employed reverse transcription and PCR (58) to amplify intracellular mRNA. Through various detection schemes cell-associated PCR products have been visualized in different applications as reporters for the presence of specific genes or microbial activity (59-65).

The visualization of mRNA has already been successfully demonstrated in single Salmonella cells $(66,67)$. Attempts to transfer the developed methodology from the Salmonella system to a bacterial species more relevant for the gut microbial ecosystem focused on bifidobacteria.

With bifidobacteria as a representative genus of the intestinal microbiota the development of an in situ PCRbased method for monitoring mRNA was initiated. The most important step in a procedure for intracellular PCR is the permeabilization of cells. The cell-wall structure needs to be penetrated to allow the components of the PCR reaction mixture (i.e. primers, DNA-polymerase and deoxyribonucleotides) to enter the interior of the cell. However, the permeabilization must not be too excessive as it may result in cell lysis and/or in diffusion of the intracellularly generated PCR products out of the cell. Hence, optimal permeabilization conditions have to be worked out. Extensive work has been devoted to optimizing permeabilization conditions for different Bifidobacterium spp.

Using an rRNA-based FISH assay based on detecting a biotinylated rRNA-targeting oligonucleotide probe and visualizing the biotin moiety by fluorophore-labelled streptavidin $\left(\mathrm{M}_{\mathrm{w}}=53 \mathrm{kDa}\right)$ the optimum permeabilization conditions were assessed. A large number of different kinds of treatments including lysozyme, proteinase $\mathrm{K}$, mutanolysin, CTAB (cetyl trimethyl ammonium bromide) and combinations of these have been tested on bifidobacteria fixed with either paraformaldehyde or ethanol. These tests led to the identification of a combined treatment with lysozyme and mutanolysin that rendered $B$. longum permeable. However, to illustrate the complexity in determining the optimal permeabilization conditions, the same treatment did not enable the uptake of large molecules in $B$. bifidum to the same extent.
In spite of these difficulties, the objective of visualizing metabolic activity in individual bacteria has not been abandoned. A method has been developed to monitor $\beta$ galactosidase activity at the single-cell level $(56,68)$. The procedure has successfully been implemented using the $\mathrm{X}$ gal substrate (producing a coloured precipitate) and $\mathrm{C}_{12^{-}}$ fluorescein-digalactoside substrate $\left(\mathrm{C}_{12}-\mathrm{FDG}\right)$ (producing a fluorescent compound). Together with population-level techniques, activity staining of native PAGE and iso-electric focusing of crude protein lysates from cultures of bifidobacteria as well as DNA micro-array-based gene expression analyses, the single-cell $\beta$-galactosidase activity method is used to decipher regulatory patterns of $\beta$-galactosidase expression in different types of bifidobacteria.

\section{CONCLUSIONS}

The days when scientists spent weeks with Petri dishes trying to isolate, purify and characterize the phenotypes of new species of bacteria are history. Today, as a result of molecular biological methods the dominant human gut bacteria have been identified. However, many faecal bacterial species present in small numbers are still unexplored. Moreover, many species have not yet been cultured and, hence, their specific role in the ecosystem is still unknown. In spite of these shortcomings, the developed methods are valuable tools for the more detailed analysis of bacterial communities. Unfortunately, their widespread use is still limited by several factors including insufficient automation of sample preparation and high costs. Nonetheless these methods have been increasingly applied to studies exploring the role of diet in influencing the composition and activity of the human gut microbiota.

\section{REFERENCES}

1. Woese CR, Fox GE. Phylogenetic structure of the prokaryotic domain: the primary kingdoms. Proc Natl Acad Sci USA 1977; 74: 5088-90.

2. Fox GE, Pechman KR, Woese CR. Comparative cataloguing of $16 \mathrm{~S}$ ribosomal ribonucleic acid: molecular approach to procaryotic systematics. Int J Syst Bacteriol 1977; 57: 44-57.

3. Moreira D, Philippe H. Molecular phylogeny: pitfalls and progress. Int Microbiol 2000; 3: 9-16.

4. Ludwig W, Strunk O, Klugbauer S, Klugbauer N, Weizenegger M, Neumaier J, Bachleitner M, Schleifer KH. Bacterial phylogeny based on comparative sequence analysis. Electrophoresis 1998; 19: 554-68

5. Palys T, Nakamura LK, Cohan FM. Discovery and classification of ecological diversity in the bacterial world: the role of DNA sequence data. Int J Syst Bacteriol 1997; 47: 1145-56.

6. Kasai H, Watanabe K, Gasteiger E, Bairoch A, Isono K, Yamamoto S, Harayama S. Construction of the gyr B database for the identification and classification of bacteria. Genome Inform Ser Workshop Genome Inform 1998; 9: 13-21.

7. Hassan AA, Khan IU, Abdulmawjood A, Lammler C. Interand intraspecies variations of the $16 \mathrm{~S}-23 \mathrm{~S}$ rDNA intergenic spacer region of various streptococcal species. Syst Appl Microbiol 2003; 26: 97-103. 
8. Anton AI, Martinez-Murcia AJ, Rodriguez-Valera F. Sequence diversity in the $16 \mathrm{~S}-23 \mathrm{~S}$ intergenic spacer region (ISR) of the rRNA operons in representatives of the Escherichia coli ECOR collection. J Mol Evol 1998; 47: 62-72.

9. Hedegaard J, Steffensen SA, Norskov-Lauritsen N, Mortensen KK. Sperling-Petersen HU. Identification of Enterobacteriaceae by partial sequencing of the gene encoding translation initiation factor 2. Int J Syst Bacteriol 1999; 49(Pt 4): 1531-8.

10. Amann R, Ludwig W, Schleifer KH. Beta-subunit of ATPsynthase: a useful marker for studying the phylogenetic relationship of eubacteria. J Gen Microbiol 1988; 134(Pt 10): 2815-21.

11. Cousineau B, Cerpa C, Lefebvre J, Cedergren R. The sequence of the gene encoding elongation factor Tu from Chlamydia trachomatis compared with those of other organisms. Gene 1992; 120: 33-41.

12. Moore WE, Holdeman LV. Human fecal flora: the normal flora of 20 Japanese-Hawaiians. Appl Microbiol 1974; 27: 961-79.

13. Bonnet R, Suau A, Doré J, Gibson GR, Collins MD. Differences in rDNA libraries of faecal bacteria derived from 10- and 25-cycle PCRs. Int J Syst Evol Microbiol 2002; 52: 757-63.

14. Hold GL, Pryde SE, Russell VJ, Furrie E, Flint HJ. Assessment of microbial diversity in human colonic samples by $16 \mathrm{~S}$ rDNA sequence analysis. FEMS Microbiol Ecol 2002; 39: 33-9.

15. Wilson KH, Blitchington RB. Human colonic biota studied by ribosomal DNA sequence analysis. Appl Environ Microbiol 1996; 62: 2273-8.

16. Amann RI, Ludwig W, Schleifer KH. Phylogenetic identification and in situ detection of individual microbial cells without cultivation. Microbiol Rev 1995; 59: 143-69.

17. Harmsen HJM, Elfferich P, Schut F, Welling GW. A 16S rRNA-targeted probe for detection of lactobacilli and enterococci in faecal samples by fluorescent in situ hybridization. Microb Ecol Health Dis 1999; 11: 3-12.

18. Pernthaler J, Pernthaler A, Amann R. Automated enumeration of groups of marine picoplankton after fluorescence in situ hybridization. Appl Environ Microbiol 2003; 69: 2631-7.

19. Loy A, Horn M, Wagner M. probeBase: an online resource for rRNA-targeted oligonucleotide probes. Nucleic Acids Res 2003; 31: 514-6.

20. Pernthaler J, Glöckner FO, Schönhuber W, Amann RI. Fluorescence in situ hybridization. In: Paul JH, ed. Marine Microbiology. Methods in Microbiology, vol. 30. San Diego: Academic Press, 2001: 207-26.

21. Hugenholtz P, Tyson GW, Blackall LL. Design and evaluation of 16S rRNA-targeted oligonucleotide probes for fluorescence in situ hybridization. Methods Mol Biol 2002; 179: 29-42.

22. Ashelford KE, Weightman AJ, Fry JC. PRIMROSE: a computer program for generating and estimating the phylogenetic range of $16 \mathrm{~S}$ rRNA oligonucleotide probes and primers in conjunction with the RDP-II database. Nucleic Acids Res 2002; 30: $3481-9$

23. Fuchs BM, Wallner G, Beisker W, Schwippl I, Ludwig W, Amann R. Flow cytometric analysis of the in situ accessibility of Escherichia coli 16S rRNA for fluorescently labeled oligonucleotide probes. Appl Environ Microbiol 1998; 64: 4973-82.

24. Franks AH, Harmsen HJ, Raangs GC, Jansen GJ, Schut F, Welling GW. Variations of bacterial populations in human feces measured by fluorescent in situ hybridization with groupspecific 16S rRNA-targeted oligonucleotide probes. Appl Environ Microbiol 1998; 64: 3336-45.

25. Vaughan EE, Schut F, Heilig HG, Zoetendal EG, de Vos WM, Akkermans AD. A molecular view of the intestinal ecosystem. Curr Issues Intest Microbiol 2000; 1: 1-12.
26. Langendijk PS, Schut F, Jansen GJ, Raangs GC, Kamphuis GR, Wilkinson MH, Welling GW. Quantitative fluorescence in situ hybridization of Bifidobacterium spp. with genus-specific 16S rRNA-targeted probes and its application in fecal samples. Appl Environ Microbiol 1995; 61: 3069-75.

27. Jansen GJ, Wildeboer-Veloo ACM, Tonk RHJ, Franks AH, Welling GW. Development and validation of an automated, microscopy-based method for enumeration of groups of intestinal bacteria. J Microbiol Methods 1999; 37: 215-21.

28. Gmur R, Guggenheim B, Giertsen E, Thurnheer T. Automated immunofluorescence for enumeration of selected taxa in supragingival dental plaque. Eur J Oral Sci 2000; 108: 393-402.

29. Singleton S, Cahill JG, Watson GK, Allison C, Cummins D, Thurnheer T, Guggenheim B, Gmur R. A fully automated microscope bacterial enumeration system for studies of oral microbial ecology. J Immunoassay Immunochem 2001; 22: 253-74.

30. Amann RI, Binder BJ, Olson RJ, Chisholm SW, Devereux R, Stahl DA. Combination of 16S rRNA-targeted oligonucleotide probes with flow cytometry for analyzing mixed microbial populations. Appl Environ Microbiol 1990; 56: 1919-25.

31. Rigottier-Gois L, Rochet V, Garrec N, Suau A, Doré J. Enumeration of Bacteroides species in human faeces by fluorescent in situ hybridisation combined with flow cytometry using 16S rRNA probes. Syst Appl Microbiol 2003; 26: 110-18.

32. Zoetendal EG, Ben-Amor K, Harmsen HJ, Schut F, Akkermans AD, de Vos WM. Quantification of uncultured Ruminococcus obeum-like bacteria in human fecal samples by fluorescent in situ hybridization and flow cytometry using 16S rRNA-targeted probes. Appl Environ Microbiol 2002; 68: 4225-32.

33. Wallner G, Erhart R, Amann RI. Flow cytometric analysis of activated sludge with rRNA-targeted probes. Appl Environ Microbiol 1995; 61: 1859-66.

34. Rigottier-Gois L, Le Bourhis A-G, Gramet G, Rochet V, Doré J. Fluorescent hybridisation combined with flow cytometry and hybridisation of total RNA to analyse the composition of microbial communities in human faeces using 16S rRNA probes. FEMS Microbiol Ecol 2003; 43: 237-45.

35. Wallner G, Fuchs B, Spring S, Beisker W, Amann R. Flow sorting of microorganisms for molecular analysis. Appl Environ Microbiol 1997; 63: 4223-31.

36. Porter J, Edwards C, Morgan JA, Pickup RW. Rapid, automated separation of specific bacteria from lake water and sewage by flow cytometry and cell sorting. Appl Environ Microbiol 1993; 59: 3327-33.

37. Suau A, Rochet V, Sghir A, Gramet G, Brewaeys S, Sutren M, Rigottier-Gois L, Doré J. Fusobacterium prausnitzii and related species represent a dominant group within the human fecal flora. Syst Appl Microbiol 2001; 24: 139-45.

38. Harmsen HJM, Prieur D, Jeanthon C. Group-specific 16S rRNA-targeted oligonucleotide probes to identify thermophilic bacteria in marine hydrothermal vents. Appl Environ Microbiol 1997; 63: 4061-8.

39. Sghir A, Gramet G, Suau A, Rochet V, Pochart P, Doré J. Quantification of bacterial groups within human fecal flora by oligonucleotide probe hybridization. Appl Environ Microbiol 2000; 66: 2263-6.

40. Marteau P, Pochart P, Doré J, Bera-Maillet C, Bernalier A, Corthier G. Comparative study of bacterial groups within the human cecal and fecal microbiota. Appl Environ Microbiol 2001; 67: 4939-42.

41. Blaut M, Collins MD, Welling GW, Doré J, van Loo J, de Vos W. Molecular biological methods for studying the gut micro- 
biota: the EU human gut flora project. Br J Nutr 2002; 87(Suppl 2): S203-11.

42. Theron J, Cloete TE. Molecular techniques for determining microbial diversity and community structure in natural environments. Crit Rev Microbiol 2000; 26: 37-57.

43. Rick WY, Wang T, Bedzyk L, Croker KM. Application of DNA microarrays in microbial systems. J Microbiol Methods 2001; 47: 257-72.

44. Taroncher-Oldenburg G, Griner EM, Francis CA, Ward BB. Oligonucleotide microarray for the study of functional gene diversity in the nitrogen cycle in the environment. Appl Environ Microbiol 2003; 69: 1159-71.

45. Bodrossy L, Stralis-Pavese N, Murrell CL, Radjewski S, Weilharter A, Sessitsch A. Development and validation of a diagnostic microbial microarray for methanotrophs. Environ Microbiol 2003; 5: 566-82.

46. Rudi K, Flateland SL, Hanssen JF, Bengtsson G, Nissen H. Development and evaluation of a $16 \mathrm{~S}$ ribosomal DNA arraybased approach for describing complex microbial communities in ready-to-eat vegetable salads packed in a modified atmosphere. Appl Environ Microbiol 2002; 68: 1146-56.

47. Small J, Call DR, Brockman FJ, Straub TM, Chandler DP. Direct detection of $16 \mathrm{~S}$ rRNA in soil extracts by using oligonucleotide microarrays. Appl Environ Microbiol 2001; 67: 4708-16.

48. El Fantroussi S, Urakawa H, Bernhard AE, Kelly JJ, Noble PA, Smidt H, Yershov GM, Stahl DA. Direct profiling of environmental microbial populations by thermal dissociation analysis of native rRNAs hybridized to oligonucleotide microarrays. Appl Environ Microbiol 2003; 69: 2377-82.

49. Urakawa H, Noble PA, El Fantroussi S, Kelly JJ, Stahl DA. Single-base-pair discrimination of terminal mismatches by using oligonucleotide microarrays and neural network analyses. Appl Environ Microbiol 2002; 68: 235-44.

50. Loy A, Lehner A, Lee N, Adamczyk J, Meier H, Ernst J, Schleifer KH, Wagner M. Oligonucleotide microarray for $16 \mathrm{~S}$ rRNA gene-based detection of all recognized lineages of sulfate-reducing prokaryotes in the environment. Appl Environ Microbiol 2002; 68: 5064-81.

51. Rudi K, Skulberg OM, Skulberg R, Jakobsen KS. Application of sequence-specific labeled 16S rRNA gene oligonucleotide probes for genetic profiling of cyanobacterial abundance and diversity by array hybridization. Appl Environ Microbiol 2000; 66: 4004-11.

52. Wang RF, Beggs ML, Robertson LH, Cerniglia CE. Design and evaluation of oligonucleotide-microarray method for the detection of human intestinal bacteria in fecal samples. FEMS Microbiol Lett 2002; 213: 175-82.

53. Guschin DY, Mobarry BK, Proudnikov D, Stahl DA, Rittmann BE, Mirzabekov AD. Oligonucleotide microchips as genosensors for determinative and environmental studies in microbiology. Appl Environ Microbiol 1997; 63: 2397-402.

54. Muyzer G, de Waal EC, Uitterlinden AG. Profiling of complex microbial populations by denaturing gradient gel electrophoresis analysis of polymerase chain reaction-amplified genes coding for 16S rRNA. Appl Environ Microbiol 1993; 59: $695-700$.

55. Zoetendal EG, Akkermans AD, de Vos WM. Temperature gradient gel electrophoresis analysis of 16S rRNA from human fecal samples reveals stable and host-specific communities of active bacteria. Appl Environ Microbiol 1998; 64: 3854-9.

56. Poulsen LK, Dalton HM, Angles ML, Marshall KC, Molin S, Goodman AE. Simultaneous determination of gene expression and bacterial identity in single cells in defined mixtures of pure cultures. Appl Environ Microbiol 1997; 63: 3698-702.
57. DeLong EF, Wickham GS, Pace NR. Phylogenetic stains: ribosomal RNA-based probes for the identification of single cells. Science 1989; 243: 1360-3.

58. Saiki RK, Scharf S, Faloona F, Mullis KB, Horn GT, Erlich HA, Arnheim N. Enzymatic amplification of beta-globin genomic sequences and restriction site analysis for diagnosis of sickle cell anemia. Science 1985; 230: 1350-4.

59. Hodson RE, Dustman WA, Garg RP, Moran MA. In situ PCR for visualization of microscale distribution of specific genes and gene products in prokaryotic communities. Appl Environ Microbiol 1995; 61: 4074-82.

60. Tani K, Kurokawa K, Nasu M. Development of a direct in situ PCR method for detection of specific bacteria in natural environments. Appl Environ Microbiol 1998; 64: 1536-40.

61. Tolker-Nielsen T, Holmstrøm K, Boe L, Molin S. Non-genetic population heterogeneity studied by in situ polymerase chain reaction. Mol Microbiol 1998; 27: 1099-105.

62. Vaid A, Bishop AH. Amplification of fluorescently labelled DNA within Gram-positive and acid-fast bacteria. J Microbiol Methods 1999; 38: 53-62.

63. Lange $\mathrm{M}$, Tolker-Nielsen $\mathrm{T}$, Molin S, Ahring BK. In situ reverse transcription-PCR for monitoring gene expression in individual Methanosarcina mazei S-6 cells. Appl Environ Microbiol 2000; 66: 1796-800.

64. Hoshino T, Noda N, Tsuneda S, Hirata A, Inamori Y. Direct detection by in situ PCR of the amoA gene in biofilm resulting from a nitrogen removal process. Appl Environ Microbiol 2001; 67: $5261-6$.

65. Tani K, Muneta M, Nakamura K, Shibuya K, Nasu M. Monitoring of Ralstonia eutropha KT1 in groundwater in an experimental bioaugmentation field by in situ PCR. Appl Environ Microbiol 2002; 68: 412-6.

66. Tolker-Nielsen T, Holmstrøm K, Molin S. Visualization of specific gene expression in individual Salmonella typhimurium cells by in situ PCR. Appl Environ Microbiol 1997; 63: 4196203.

67. Holmstrøm K, Tolker-Nielsen T, Molin S. Physiological states of individual Salmonella typhimurium cells monitored by in situ reverse transcription-PCR. J Bacteriol 1999; 181: 1733-8.

68. Lewis PJ, Nwoguh CE, Barer MR, Harwood CR, Errington J. Use of digitized video microscopy with a fluorogenic enzyme substrate to demonstrate cell- and compartment-specific gene expression in Salmonella enteritidis and Bacillus subtilis. Mol Microbiol 1994; 13: 655-62.

69. Heilig HG, Zoetendal EG, Vaughan EE, Marteau P, Akkermans AD, de Vos WM. Molecular diversity of Lactobacillus spp. and other lactic acid bacteria in the human intestine as determined by specific amplification of $16 \mathrm{~S}$ ribosomal DNA. Appl Environ Microbiol 2002; 68: 114-23.

70. Schwiertz A, Hold GL, Duncan SH, Gruhl B, Collins MD, Lawson PA, Flint HJ, Blaut M. Anaerostipes caccae gen. nov., sp. nov., a new saccharolytic, acetate-utilising, butyrate-producing bacterium from human faeces. Syst Appl Microbiol 2002; 25: $46-51$

71. Lawson PA, Song Y, Liu C, Molitoris DR, Väisänen ML, Collins MD, Finegold SM. Anaerotruncus colihominis gen. nov., sp. nov., from human faeces. Int J Syst Evol Microbiol 2004; 54: 413-7.

72. Rautio M, Eerola E, Väisänen-Tunkelrott ML, Molitoris DR, Lawson PA, Collins MD. Reclassification of Bacteroides putridinis (Weinberg et al. 1937) in a new genus Alistipes gen. nov., as Alistipes putridinis comb. nov., and description of Alistipes finegoldii sp. nov., from human sources. Syst Appl Microbiol 2003; 26: 182-8. 
73. Wolin MJ, Miller TL, Collins MD, Lawson PA. Formate dependent and homoacetic acid fermentation by a bacterium from human feces. Description of Bryantella formatexigens gen. nov., sp. nov. Appl Environ Microbiol 2003; 69: 6321-6.

74. Finegold SM, Väisänen ML, Molitoris DR, Tomzynski TJ, Song Y, Liu C, Collins MD, Lawson PA. Cetobacterium somerae sp. nov. from human feces and emended description of the genus Cetobacterium. Syst Appl Microbiol 2003; 26: $177-81$.

75. Song Y, Liu C, Molitoris DR, Tomzynski TJ, Lawson PA, Collins MD. Clostridium bolteae sp. nov., isolated from human sources. Syst Appl Microbiol 2003; 26: 84-9.

76. Steer T, Collins MD, Gibson GR, Hippe H, Lawson PA. Clostridium hathewayi sp. nov., from human faeces. Syst Appl Microbiol 2001; 24: 353-7.

77. Taras D, Simmering R, Collins MD, Lawson PA, Blaut M. Reclassification of Eubacterium formicigenerans Holdeman and Moore 1974 as Dorea formicigenerans gen. nov., comb. nov., and description of Dorea longicatena sp nov., isolated from human faeces. Int J Syst Evol Microbiol 2002; 52: 423-8.

78. Simmering R, Taras D, Schwiertz A, Le Blay G, Gruhl B, Lawson PA. Ruminococcus luti sp. nov., isolated from a human faecal sample. Syst Appl Microbiol 2002; 25: 189-93.

79. Hold GL, Schwiertz A, Aminov RI, Blaut M, Flint HJ. Oligonucleotide probes that detect quantitatively significant groups of butyrate-producing bacteria in human feces. Appl Environ Microbiol 2003; 69: 4320-4.

80. Harmsen HJ, Wildeboer-Veloo AC, Grijpstra J, Knol J, Degener JE, Welling GW. Development of 16S rRNA-based probes for the Coriobacterium group and the Atopobium cluster and their application for enumeration of Coriobacteriaceae in human feces from volunteers of different age groups. Appl Environ Microbiol 2000; 66: 4523-7.

81. Harmsen HJ, Raangs GC, He T, Degener JE, Welling GW. Extensive set of 16S rRNA-based probes for detection of bacteria in human feces. Appl Environ Microbiol 2002; 68: 2982-90.

82. Tannock GW, Munro K, Harmsen HJ, Welling GW, Smart J, Gopal PK. Analysis of the fecal microflora of human subjects consuming a probiotic product containing Lactobacillus rhamnosus DR20. Appl Environ Microbiol 2000; 66: 2578-88.

83. Manz W, Amann R, Ludwig W, Vancanneyt M, Schleifer KH. Application of a suite of $16 \mathrm{~S}$ rRNA-specific oligonucleotide probes designed to investigate bacteria of the phylum cytophaga-flavobacter-bacteroides in the natural environment. Microbiology 1996; 142(Pt 5): 1097-106.

84. Schwiertz A, Le Blay G, Blaut M. Quantification of different Eubacterium spp. in human fecal samples with species-specific 16S rRNA-targeted oligonucleotide probes. Appl Environ Microbiol 2000; 66: 375-82.

85. Wallner G, Amann RI, Beisker W. Optimizing fluorescent in situ hybridization with rRNA-targeted oligonucleotide probes for flow cytometric identification of microorganisms. Cytometry $1993 ; 14: 136-43$.

86. Alm EW, Oerther DB, Larsen N, Stahl DA, Raskin L. The Oligonucleotide Probe Database. Appl Environ Microbiol 1996; 62: 3557-9. 
Copyright of Microbial Ecology in Health \& Disease is the property of Taylor \& Francis Ltd and its content may not be copied or emailed to multiple sites or posted to a listserv without the copyright holder's express written permission. However, users may print, download, or email articles for individual use. 